\title{
Structuring Tenses of English by Islamic Higher Education Students: A Case Study at Universitas Sains Alqur'an
}

\author{
Abdur Rofik $1, \mathrm{a}^{*}$, and Sahid ${ }^{1, \mathrm{~b}}$ \\ ${ }^{1}$ Faculty of Language and Literature, Universitas Sains Alqur'an, Wonosobo, Indonesia \\ a abdur.rofik32@yahoo.com; b sahid.jpn123@gmail.com \\ ${ }^{*}$ Corresponding Author \\ Whatsapp Number [081228427784]
}

How to Cite: Rofik, A., \& Sahid. (2019). Structuring Tenses of English by Islamic Higher Education Students: A Case Study at Universitas Sains Alqur'an. International Journal for Educational and Vocational Studies, 1(1), 25-30. DOI: https://doi.org/10.29103/ijevs.v111.1391

\section{ARTICLE HISTORY}

Received: 16 March 2019

Revised: 18 April 2019

Accepted: 22 April 2019

\section{KEYWORDS}

Tenses

Surface structures

Islamic higher education

\section{ABSTRACT}

The aims of this study are to reveal errors in structuring tenses and to find out errors of surface structures committed by Islamic Higher Education Students of Universitas Sains Alqur'an, Wonosobo. Subject of the study is 28 students of Islamic Relegion Education Study Program of Tarbiyah Sciences and Teacher Training Faculty of Universitas Sains Alqur'an, Wonosobo in the first semester of the 2018/2019 Academic Year. Data collecting was conducted through written work instruments. In analyzing the data, the writer reads the data sources, indentifies the errors, classifies them, and especially for tense errors, the writer adds the step of data analysis, namely calculating the errors to find the percentage. The results convey that with regard to tense aspects, the student errors involve simple present $13,54 \%$, present progressive $30,2 \%$, present perfect $28,64 \%$, and present perfect progressive tense $27,6 \%$. Then, with regard to surface structures, the factors of errors committed are omission, addition, misformation, and misordering.

This is an open access article under the CC-BY-SA license.

\section{INTRODUCTION}

Islamic higher education students were found commiting errors in applying tense aspects. They seem not confident to select the appropriate tenses in particular points of view even though they have learned those materials since they were junior high school students even some elementary schools in Indonesia with good acreditation give English lessons for their students. Unfortunately, the difficulty of tense or widely grammar has still been involved in student understanding until their higher education level.

The errors in English learners are as reflected in some contemporary studies which consider English as both foreign and second language perspective that show EFL and ESL learners often make errors (Mali, 2016), interlingual and intralingual errors (Rofik, 2018). Futhermore, Rofik discovered interlingual erros made by the EFL students are caused by students' first language (Indonesia) which influences their learned language (English). Then, intralingual errors made by the students are their ignorance of target language rules, precisely overlooking coocurrence restrictions.

In accordance with Rofik, Asni \& Susanti (2018) revealed that students of eight grade of SMP Negeri 20 Kota Jambi committed the errors in writing recount text that are caused by interlingual and intralingual transfer.
Meanwhile, Mali (2016) found that Indonesian undergraduates in EFL classrooms, particularly in writing class, needed conscious focus on grammatical aspects.

Relevant to Rofik's findings, Kurniawan's research (2018) in analyzing translation of English-language teaching materials found that interlingual and intralingual interference were still involved in children's literature translation project conducted by students of Early Childhood Education Study Program. Furthermore, the categories of interlingual interference are general misuse of words, structural mistaken, misplacing of words and omission while intralingual interference categories are overgeneralization, ignorance of rule restriction, incomplete application of rules, and false concept hypotheses. Another research conducted by Koman et al (2019) revealed that undergraduate students of English Education Study Program still made some errors in their translation. And the three most prominent error categories are grammar, syntax, and faithfulness errors. In addition, Khatri (2015) revealed that students learning English who cannot perform correct English writing are due to silly mistakes.

Related to L2 learning, Brown stated (2007, p. 102) that the role of interference in ESL is common to be stressed as L1 mostly effects to L2. Considering this case, it seems that 
the study of errors is still needed to overcome specific learner problems. In accordance with this argument, recent research conducted by Julialy and Abetnego (2019) stated that Indonesian senior high school students involved ill-formed sentence contraction in writing descriptive texts. Those errors were prepositions, articles, singular and plural nouns, adjectives, tenses, concord, and possessive cases.

A lot of errors that rise on structuring English sentences are due to many factors. In this study the writer focuses on aspects of tenses. Then the writer also analyzes the surface structures of the sentences. Related to tenses, Declerck et al (2006, p. 94) stated that tense is the pairing of a morpho-syntactic form with a meaning, the meaning being the specification of the temporal location of a situation. Sharply, Gear (1993, p. 143) stated that verbs indicate a point of time in the past, present, or future. Furthermore, Frank (1972, p. 52) stated that the most common interpretation of tense is a semantic one. He added that each tense roughly indicates a kind of time. On account of this structure rules, tense is considered difficult for some non first language speakers since non first speakers should agree the verbs of the sentences and their time signal involved in the sentences while their first language often does not have this kind of rule. Beside, subjects of the sentences also should agree with their verbs of the sentences.

The difficulty of constructing tense was reflected in students' responses. They produced some utterances as presented in the following:

1. Smith has been going to school every day.

2. He and I now is being friends.

3. Does Mary drink lemon juice at the moment?

Based on above utterances, the errors committed by the students occur in various verb tense. The verb forms of tense seem not accord with their time points of view and subject-verb agreement. Furthermore, the students look to make errors of misformation. Then, the data showed us that students faced simple present and present progressive tense as problems.

\subsection{Tenses}

Frank (1972, p. 52) argued that tense is usually discussed closely with verb forms. Furthermore, he insisted that first, tense is indicated through semantic interpretation. He categorizes tense to be present, past, and future. While a second interpretation of tense is based on verb forms themselves. Based on linguists' point of view, Frank tended to work with six-tense time system. He raised his argument with the fact that those six-tense are the most common items found in English textbooks for EFL or ESL learners. The second interpretation of tense is in line with Swan (1995, p. 10) who stated tenses as active verb forms. But different from Frank, Swan divided tense classification to be twelve types. evaluate how far the students are able to apply grammatical roles in structuring utterances correctly. Those tense are simple present, present progressive, present perfect, and present perfect progressive.

The study of error analysis is essential. Corder (1982, p. i) stated that “... learners' error is part of the systematic study of the learners' language which is itself necessary to an understanding of the process of second language acquisition". It implies that we are able to evaluate learners' language acquisition with doing error analysis research. Through this research, we can maintain which aspects that the learners have understood and haven't. So that we can lead language learning with appropriate plans to develop learner's language skill.

The problems of tenses remain difficult not only for EFL students of Indonesia but also for EFL or ESL students from another country. Sukasame et al (2014) found that university students of Thai still made errors for seven tenses, namely present continuous tense, future simple tense, present simple, past continuous tense, present perfect tense, past simple tense, and past perfect tense.

\subsection{Taxonomy of Surface Structures}

EFL Learners are often found making erroneous alters in transferring texts to target language. Muhsin (2016) revealed that students of Junior High School in Makassar involved errors in using simple present. Those errors are addition, omission, missformation, and improper ordering. In this study, the writer uses James' categorization of errors (2013, pp. 106-113). Those are omission, addition, misformation, misordering, and blends. In earlier argumentation Dulay et al (1982, p. 150) stated that surface strategy taxonomy categorized the errors to be omission, addition, misformation, and misoreder.

a. Omission is different from ellipsis. The first is ungrammatical and the second is not. This error is usually caused by the effect of function words. It is labeled by unpresent elements that are needed to construct well-order utterances.

b. Addition as parts of errors can be categorized from regularization or irregularization. This is as the case which happed in past forms of verb such as writing buyed in spite of bought. Addition can also appear in double marking which is defined as adding the particular items that are not required in linguistics construction. Then, errors of edition can also be due to simple addition covering for all addition which is not in regularization, irregularization, and double marking. 
c. Misformation is defined as wrong forms of structure and morpheme use. James (2013, p. 108) sometime tended to use the terms of misselection rather than misformation based on certain reasons. Furthermore, He critized utterances as "I read that book" when it is called as misformation since that should be misformed from this.

d. Misordering is categorized by linguistical competence which means to order the right forms in the right structures. James (2013, p. 110) stated that in English certain word classes seem to be especially sensitive to misordering, such as interrogatives, adverbials, and adjectives.

e. Blends happen when the learners combine two parts of items in structuring sentences. In other word, blend is caused when part of target items hamper another item. For example, a) this problem is difficult to solve, b) this problem is difficultly solved. Both are Standard English and c) as blend result is written as "this problem is difficultly to be solved".

This study proposes the same as Ricard's statement related to error analysis (EA). EA is conducted to present the constraints faced by learners of EFL or ESL. The Importance of second language acquisition (SLA) research rises as this research can grasp the problems of learners and propose the solution. Specifically Richard (1973, p. 15) stated that observation of second language acquisition together with language learning in formal classroom is needed to provide input to develop pedagogical grammar teaching.

\section{METHODS}

This study involved a case study. The researcher collected the data through written data. The data were then analyzed systematically. Written data were analyzed using Mills and Gay statements (2016, pp. 582-584) namely reading, describing, and classifying. Then, to get precise error findings after classifying the data, the writer made proportion of errors. The writer calculated the proportion of errors. The formula is as below.

$$
\begin{aligned}
& \mathrm{E}=\underline{\mathrm{TE}} \times 100 \% \\
& \mathrm{~N} \\
& \mathrm{TE}=\text { the proportion of errors } \\
& \mathrm{N}=\text { the total number of errors }
\end{aligned}
$$

The description of the written data dealt with tense errors committed by students of Islamic Relegion Education Study Program of Tarbiyah Sciences and Teacher Training Faculty of Universitas Sains Alqur'an, Wonosobo. The subject of the study was 28 students. The class actually consisted of 34 students, but 6 students did not submit the answer sheets. Then, the data were collected in first semester of academic year 2018/2019.

The instrument of written data taken for this study was multiple choice, Indonesia-English translation, and error analysis tests. The test was proposed to get information about students' errors when they structured utterances, and to measure the students' ability dealt with present tense usage and surface structure contraction.

\section{RESULTS AND DISCUSSION}

Results and discussions run based on the the purpose of the study, i.e; to reveal (1) the errors commited by Islmaic higher education in structuring tense. Then, after reading the data, the reseacher discussed the findings through identifying, classifying and counting, (2) errors of surface structures committed by the students.

\subsection{Error Description}

Error description is a step the reseacher did to identify and to describe the students' errors appearing in their answer sheets related to tense from the tasks that the reseacher distributed. The reseacher then explained the number of errors made by the students. Table 1 shows the students' errors.

Table 1. Description of Sstudents' Errors

\begin{tabular}{llc}
\hline No. & \multicolumn{1}{c}{ Tenses } & Surface Structures \\
\hline 1 & Simple present & Omission \\
2 & Present progressive & Addition \\
3 & Present perfect & Misformation \\
4 & Present perfect progressive & Misordering \\
\hline
\end{tabular}

Table 2. Number of Errors in Structuring Tenses

\begin{tabular}{ccc}
\hline Number of students & Number of errors & number of test items \\
\hline 28 & 192 & 280 \\
\hline
\end{tabular}

\subsection{Errors of Tenses}

The reseacher found that the total number of errors commited by the students in constructing utterances based on perspective of tense were 192. The errors involved simple present, present progressive, present perfect, and present perfect progressive. The study revealed that the mean of errors, which was resulted in dividing the percentage of total errors by the total students participated, is $68,57 \%$. It means the level of students' understanding is 
good enough. To get clear discussion, the reseacher discussed the findings one by one as the following. The errors presented in this discussion are the samples from all the errors commited by the students. This is done since the errors occured in the same case.

\subsubsection{Errors of Simple Present Tense}

Table 3. Errors of Simple Present

\begin{tabular}{cll}
\hline No. & Students' response & Possible correction \\
\hline 1 & Smith has gone to teach English every & Smith goes to teach English \\
& day & every day. \\
2 & What Andi is studied in program studie & Is Andi a student of Islamic \\
& English education? & education study program? \\
\hline
\end{tabular}

The above errors indicated that the students did not understand how to construct the utterances correctly. In case 1 , the time signal "every day" indicated that the sentence needed simple present forms. It means the main verb should select present forms with s-additional since the subject is third person "Smith". In case 2, the students seemed difficult to construct interrogative sentence with yes-no response. the error of structuring interrogative sentence with third person as subject of the sentence appears when the student wrote question word "what" instead of auxiliary verb "is". Furthermore, the utterance made by the the student looked confusing as the student wrote a question word first then it was followed by a subject, by be "is, and by past participle "studied" form.

\subsubsection{Errors of Present Progressive Tense}

Table 4. Errors of Present Progressive

\begin{tabular}{cll}
\hline No. & \multicolumn{1}{c}{ Students' responses } & \multicolumn{1}{c}{ Possible correction } \\
\hline 1 & $\begin{array}{l}\text { Has Mary drunk lemon juice at the } \\
\text { moment? }\end{array}$ & $\begin{array}{l}\text { Is Mary drinking lemon juice at the } \\
\text { moment? }\end{array}$ \\
2 & $\begin{array}{l}\text { Mirna and I am not pluck flower in } \\
\text { garden now. }\end{array}$ & $\begin{array}{l}\text { Mirna and I am not pluck flower in } \\
\text { garden now. }\end{array}$ \\
\hline
\end{tabular}

The errors related to present progressive tense are characterized by the use of incorrect structure which is not equivalent of subject-verb agreement and verb-time signal agreement. Prepositional phrase as adverbial time "at the moment", for number 3 , indicates that the sentence must be in present progressive tense, but the student committed the errors by placing present perfect tense form. The student looked constructing ill-form structures in number 4 . The problems are the use of the auxiliary and main verb of the sentence.

\subsubsection{Errors of Present Perfect Tense}

Table 5. Errors of Present Perfect

\begin{tabular}{cll}
\hline No. & \multicolumn{1}{c}{ Students' responses } & \multicolumn{1}{c}{ Possible correction } \\
\hline 1 & His father lives in Germany since & His father has lived in Germany \\
& 2017. & since 2017. \\
2 & $\begin{array}{l}\text { Segitiga bermuda already to be } \\
\text { misteri to arrive now. }\end{array}$ & $\begin{array}{l}\text { Bermuda triangle has been a } \\
\text { mystery until now. }\end{array}$ \\
\hline
\end{tabular}

Present perfect tense errors, in table 5, are characterized by the incorrect performances of using incorrect subject-verb and verb-time signal agreement. Furthermore, the students supplied auxiliary and main verb incorrectly as those verbs do not agree with their time signals.

\subsubsection{Errors of Present Perfect Progressive Tense}

Table 6. Errors of Present Perfect Progressive

\begin{tabular}{ccc}
\hline No. & \multicolumn{1}{c}{ Students' response } & \multicolumn{1}{c}{ Possible correction } \\
\hline 1 & $\begin{array}{l}\text { Does Stave drive his car for six } \\
\text { hours? }\end{array}$ & $\begin{array}{l}\text { Has Stave been driving his car for } \\
\text { six hours? }\end{array}$ \\
\hline
\end{tabular}

The error of present perfect progressive is caused by the wrong uses of verb of the sentence, either auxiliary or main verbs.

\subsubsection{Percentage of Errors}

To get the precise number of errors, the writer count the percentage of each tense error. The percentage of errors is counted based on the following formula:

$\mathrm{E}=\underline{\mathrm{TE}} \times 100 \%$

$\mathrm{N}$

Based on the table 1 in which the researcher classified the errors into several types of tense. The result of error proportion can be seen in table 7 .

Table 7. Percentage of each tense error

\begin{tabular}{lcc}
\hline \multicolumn{1}{c}{ Types of Errors } & Number of errors & Percentage \\
\hline Simple present & 26 & $13,54 \%$ \\
Present progressive & 58 & $30,2 \%$ \\
Present perfect & 55 & $28,64 \%$ \\
Present perfect progressive & 53 & $27,6 \%$ \\
\hline \multicolumn{1}{c}{ Total } & 192 & $100 \%$ \\
\hline
\end{tabular}

Figure 1. Tense errors

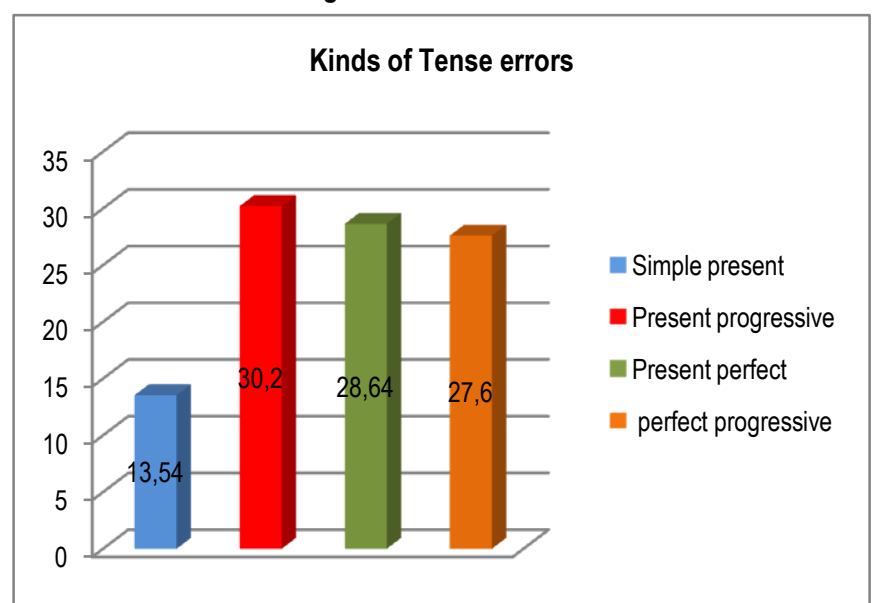

As seen at chart 1 above, the students committed errors in all present tenses. The occurrence errors for simple present is $13,54 \%$, for present progressive $30,2 \%$, for present perfect is $28,64 \%$, and for present perfect progressive is $27,6 \%$.

To reveal the most and the least dominant occurrence of errors, the writer first calculates mean of $100 \%$. The formulation is $100 \%$ which is divided by 4 kinds of tense errors. It means the mean $[\mathrm{M}]$ is $25 \%$. Secondly, the writer calculates the error of every tense. Every error, whose (E $\mathrm{M})$ is plus, is considered to be dominant. In the contrary, 
when the result of $(\mathrm{E}-\mathrm{M})$ is minus, the error is considered less dominant.

Table 8. Level of Dominant Errors

\begin{tabular}{lcc}
\hline \multicolumn{1}{c}{ Types of Errors } & $\mathrm{E}$ & $\mathrm{E}-\mathrm{M}$ \\
\hline Simple present & $13,54 \%$ & $-11,46$ \\
Present progressive & $30,2 \%$ & 5,2 \\
Present perfect & $28,64 \%$ & 3,64 \\
Present perfect progressive & $27,6 \%$ & 2,6 \\
\hline
\end{tabular}

Based on the table above, the level of dominant errors for simple present is $-11,46$, for present progressive is 5,2 , for present perfect is 3,64 , and for present perfect progressive is 2,6 . It means that the most occurrence error is present progressive. And the least occurrence error is simple present.

\subsection{Errors of Surface Structures}

In constructing the utterances, the students should apply grammatical rules correctly. Grammatical rules involve not only subject-verb or verb and point of view agreement but also all linguistics elements that are needed to make the utterances meaningful. Therefore, the utterances which do not follow the grammatical rules then are indicated engaging errors. Furthermore, this study classifies the errors to be omission, addition, misformation, misordering, and blends.

\subsubsection{Omission}

Omission is commonly caused by the effect of function words. It is known by unpresent elements which are needed to construct well-order utterences. the findings indicated that the students omit a (as article), s (as plural marks). Here are the examples of omission errors made by the students.

1. Mirna and I have not plucked flower.

2. Bermuda triangle has to be mystery until now.

Possible correction of the utterences should be:

1. Mirna and I have not picked flowers.

2. Bermuda triagle has been $\boldsymbol{a}$ mystery until now.

\subsubsection{Addition}

Addition is error that can be indicated by double marking elements that are not required, regulerization and irregulerization forms.

1. Marwan is not being lazy boy.

2. Mirna and me I are not picking flowers in the garden now.

Possible correction of the sentences should be:

1. Marwan is not a lazy boy.

2. Mirna and I are not picking flowers in the garden now

\subsubsection{Misformation}

Misformation is defined as wrong forms of structure and morpheme use. In this case the students supply something to construct the utterences, but it is incorrect. Here are the examples of misformation errors conducted by the students.

1. Does Mary drink lemon juice at the moment?

2. His father is living in Germany since 2017.

Possible correction of the sentences should be:

1. Is Mary drinking lemon juice at the moment?

2. His father has lived in Germany since 2017.

\subsubsection{Misordering}

Misordering is defined as linguistical competence meaning to order the right forms in the right structures. It means that the errors are categorized by incorrect placement of a morpheme or sequence. The errors can be seen in following sample sentences.

1. Triagle Bermuda has been a mystery until now.

2. What Andi is student in_Programs Study Islamic

\section{Education?}

Possible correction of the sentences should be:

1. Bermuda Triagle has been a mystery until now.

2. Is Andi a student in Islamic Relegious Education

\section{Study Program?}

Based on the findings above, the errors of surface taxonomy made are in kinds of omission, addition, misformation, and misordering. This finding strengthens Handayani's study stating (2019) that Indonesian EFL students made errors of writing when their writing were examined with theory of surface strategy taxonomy of Dulay, Burt, and Krashen.

\section{CONCLUSION}

Based on the findings, the writer found there were 192 total number of errors from 280 total number of test items. The students made various errors in constructing utterances based on tense point of view. The errors committed are simple present $(13,54 \%)$, present progressive $(30,2 \%)$, present perfect $(28,64 \%)$, and present perfect progressive $(27,6 \%)$. The errors are caused either by the lack awareness of the students to agree subjects of the sentences and their verb form or by the lack of understanding of the students to construct verb and time signal agreement.

Furthermore, the surface structure errors in structuring utterances committed by the students are caused by four specific factors, namely: omission, addition, misformation, and misordering. Considering the results of this study, the writer seems to give some suggestion to develop the process of English learning for Islamic Higher Education Students dealing with aspects of tenses and 
surface structure strategy in order to improve students' ability and competency.

1. Teachers should give clear explanation of English grammar, particularly related to tenses, such as the rules of subject-verb agreement, and verb-time signal agreement.

2. Teachers should encourage that the students to be able to use present tenses, especially present progressive tense in sentences correctly.

3. Teachers are encouraged to measure students' understanding through timetable evaluation. This step is hoped to decide the following teaching learning process, whether the students needs reinforce programs or not.

4. Students are encouraged to develop their ability to construct sentences in various present tenses correctly through peer correction, writing exercises, teacher feedback and so on.

5. Students should increase their awareness of structuring correct sentences from aspects of surface structures.

\section{REFERENCES}

Asni S. L., Susanti, S. (2018). An analysis of grammatical errors in writing recount text at the eight grade of SMP negeri 20 Kota Jambi. International Journal of Language Teaching and Education, 2(2), 131-144. DOI: http://doi.org/10.22437/ijolte.v2i2.5205

Brown, H. D. (2007). Principles of Language Learning and Teaching $\left(5^{\text {th }}\right.$ ed.). New York: Pearson Education, Inc.

Corder, S. P. (1982). Error analysis and interlanguage. Oxford: Oxford University Press.

Declerck, R. et al. (2006). The Grammar of the English Verb Phrase: A comprehensive analysis. Berlin: Walter de Gruyter GmbH \& Co. KG.

Dulay, H. C., et al. (1982). Language Two. Oxford: Oxford University Press.

Frank, M. (1972). Modern English: A Practical Reference Guide. New Jersey: Prentice-Hall, Inc.

Gear, J. (1993). Cambridge Preperation for the TOEFL Test. Cambridge: Cambridge University Press.

Handayani, R., Ihsan, D., \& Mirizon, S. (2019). Interlanguage analysis of syntaxtic and diction errors found in theses written by magister students. International Journal of Indonesian Education and Teaching. 3(1). 102-116. DOI: https://doi.org/10.24071/ijiet.2019.030110

James, C. (2013). Errors in Language Learning and Use: Exploring error analysis. New York: Routledge.

Julialy, H. \& Abetnego, D. (2019). A Preliminary study on EFL students' grammatical competence in descriptive writing task. Journal of Language and Literature. 19(01). 90-100. DOI: https://doi.org/10.24071/joll

Khatri, B. (2015). Teaching English trough silly mistakes of the students: An action research. International Journal for Research in Educational Studies. 1(1). 1-21. Retrieved from https://gnpublication.org/index.php/es/article/view/891

Koman, H. N. N., et al. (2019). Translation errors in students' Indonesian-English transltion practice. English Education Journal. 9(2). 206-218. Retrieved from https://journal.unnes.ac.id/sju/index.php/eej/article/view/29372 DOI: https://doi.org/10.15294/eej.v9i2.29372

Kurniawan, M. (2018). the Analysis of interlingual and intralingual interference in children's literature translation project. Celt: A Journal of
Culture, English Language, Teaching \& Literature. 18(2). 229-244. DOI: https://doi.org/10.24167/celt.v18i2

Mali,Y. C. G. (2016). Writing grammatical sentences: Voices of Indonesian undergraduates in EFL classrooms. Jurnal Pendidikan Bahasa dan Sastra. 16(1), 14-22. DOI: http://dx.doi.org/10.17509/bs_jpbsp.v15i2

Mills, G. E. \& Gay, L. R. (2016). Educational Research: Competencies for Analysis and Application 11th edition. Boston: Pearson Education Limited.

Muhsin, M. A. (2016). Analyzing the students errors in using simple present (A case study at junior high school in Makassar. Pasific Science Review B: Humanities and Social Sciences. 2(3), 81-87. DOI: https://doi.org/10.1016/j.psrb.2016.09.006

Richards, J. C. (1973). Error Analysis: Perspective of Second Language Acquisition. New York: Longman.

Rofik, A. (2018). Grammatical errors made by secondary students in writing: from interlingual to intralingual. JOURNAL OF ENGLISH LANGUAGE AND LANGUAGE TEACHING (JELLT), 2(2), 19-28. Retrieved from http://jurnal.ustjogja.ac.id/index.php/JELLT/article/view/3270

Sukasame, N. et al. (2014). A Study of errors in learning English grammatical structures on tenses of Matthayomsuksa 4 students of the demonstration school, KhonKaen University. Proceeding of 5th World Conference on Educational Sciences, Feb. 21, Procedia Social and Behavioral Sciences, pp: 1934-1939. DOI: https://doi.org/10.1016/j.sbspro.2014.01.498

Swan, M. (1995). Practical English Usage (2nd ed.). Oxford: Oxford University Press. 